Original Research

\title{
The Effect of Storytelling Using Finger Puppets on Anxiety in Hospitalized Preschool Children
}

\author{
Shelfi Dwi Retnani Putri Santoso ${ }^{1 *} \&$ Suci Nurjanah ${ }^{1}$ \\ ${ }^{1}$ STIKes Bahrul Ulum Jombang, Jombang, Indonesia
}

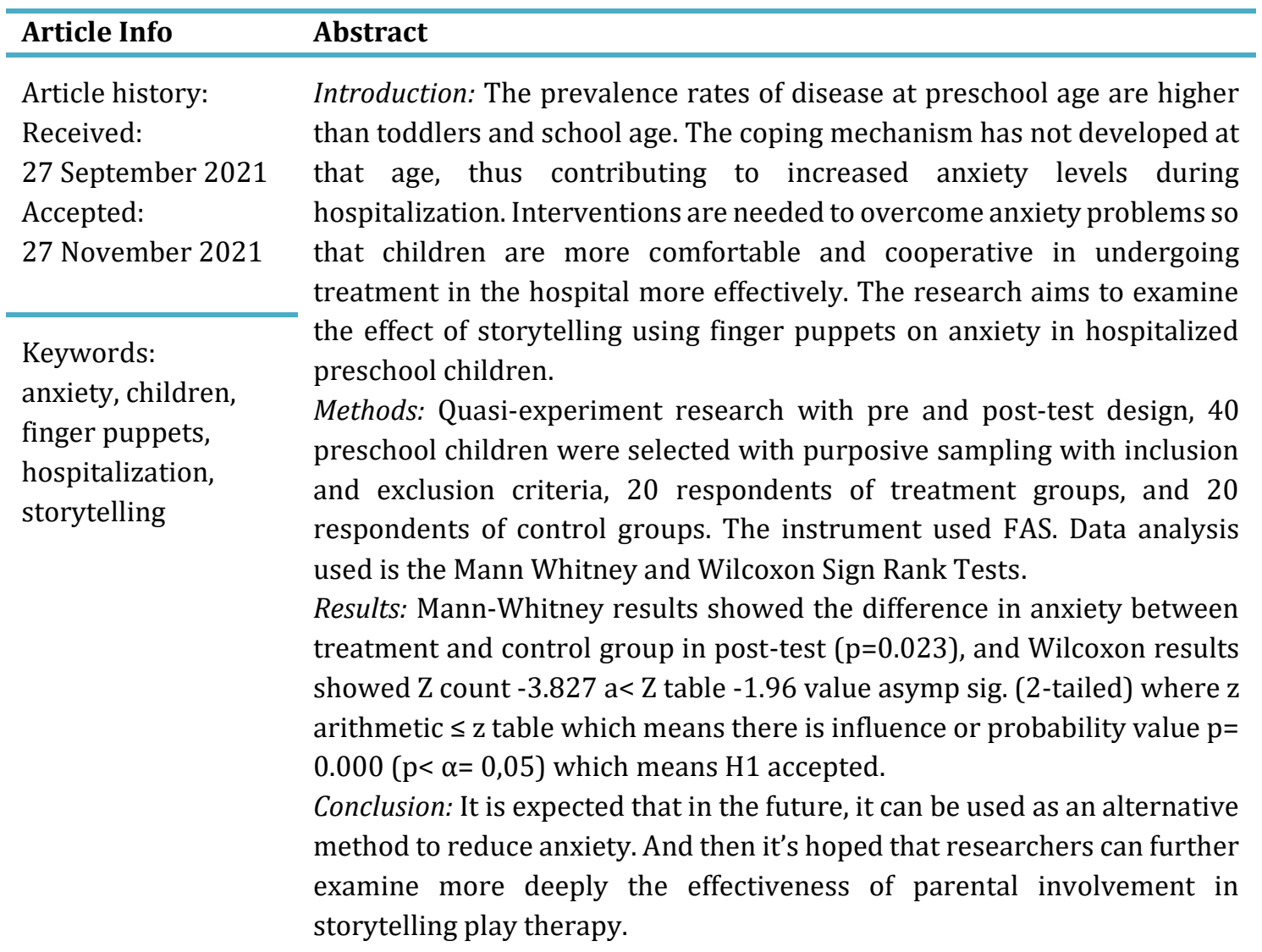

*Corresponding Author:

e-mail: shelfi.dr.putri@gmail.com 


\section{INTRODUCTION}

Prevalence of child disease in Indonesia, according to the age group of 0-2 years by $15.14 \%$, ages $3-5$ years by $25.8 \%$, ages $6-12$ years as much as $13.91 \%$ when compared to the overall population, the prevalence of preschool-age disease is higher at $25.8 \%$ [1]. This condition allows the child to be treated in a hospital (Hospitalization). Hospitalization causes traumatic events and stress in an uncertain environment for the child and family, whether it is an effective procedure that has been planned in advance or of an emergency that occurs due to trauma [2]. According to researchers [3], the incidence of anxiety in 30 preschool-aged children admitted to Buton hospital 70\% experienced moderate anxiety, and $23.3 \%$ experienced severe anxiety and 6.6\% experienced mild anxiety. Stressors that occur in children associated with hospitalization can cause various impacts. Short-term impacts, such as regression, namely loss of control, displacement, aggression (denial), withdrawing, protest behavior, and more among them experiencing fear when health workers will do the treatment [4].

The long-term impact of anxiety on children has a significant influence on their life function if not addressed early, which will be comorbid with other mental disorders and developmental disorders in children[5]. There needs to be quick action so that children become more comfortable and cooperative to medical treatment measures, one of which is an intervention with play therapy [6].
Play therapy is a fun activity for children and is the most effective activity in reducing anxiety, fear, and coping in the face of stress [7]. Play therapy can help lower anxiety and negative emotions in hospitalized children [8]. Research [9] suggests play therapy with storytelling can decrease anxiety and behavioral disorders in children with surgical preparations. It is also supported by research conducted [10], fairy tale therapy can provide happiness and smiles to hospitalized children, to reduce anxiety. Based on the background, we chose play therapy with storytelling modified using finger puppets as an intervention to reduce anxiety in preschoolaged children treated at Jombang Hospital. The research aims to examine the effect of storytelling using finger puppets on anxiety in hospitalized preschool children.

\section{METHODS}

This study is a quasi-experiment with the design of "one group pre and post-test with control group design" where there is an intervention group that gets storytelling modification therapy and the control group is given a storybook and treated as usual. This study was conducted at Jombang Hospital, the population of all children in the Srikandi Room Jombang Hospital. Forty children were selected with purposive sampling with inclusion and exclusion criteria, 20 children to the treatment group and 20 respondents to the control group. The inclusion criteria of this study is preschool-aged children (3-6 years), hospitalized children in the Srikandi Room of Jombang Hospital, children who want to be invited to communicate, and for the exclusion 
criteria of this study is children with multicomplications with decreased awareness, children with hearing loss.

The implementation of the study begins by determining the appropriate sample of the needs of the researcher according to the inclusion criteria. Divided respondents into treatment groups and control groups. The intervention group and control group took anxiety measurements first. The control group was treated according to treatment in the Srikandi Room Jombang Hospital without storytelling intervention. The treatment group performed one storytelling intervention modified using finger puppet once for 10 minutes, and then post-test was done 30 minutes after the intervention. Anxiety measurement using the FAS (Face Anxiety Scale) measuring tool developed by McMurtry (2010) in [11]. The rating scale has the lowest score 0 showed no anxiety, score 1 showed mild anxiety, score 2 showed moderate anxiety, score 3 showed severe anxiety and the highest score 4 showed panic.

The inferential analysis used in the study was ordinal (categorical) data using the Wilcoxon Signed Ranks test to look at differences before and after the intervention and the Mann-Whitney test to look at differences in post-intervention values in the control and treatment groups.

The research conducted from May to July 2021. The ethical test was conducted at the Ethics Commission of Health Research of Jombang Regional General Hospital with No.24 /KEPK/IV/2021.

\section{RESULTS}

A total of 40 respondents were divided into 20 respondents of the treatment group and 20 respondents of the control group who were actively involved in the study. Gender in both male and female respondents was 11 vs. 9 (55\% vs. $45 \%$ ) in the treatment group and 10 vs. 10 (50\% vs. $50 \%)$ in the control group. Half of the 5-year-old respondents were 16 (40\%) in both groups, in the treatment and control group of $8(40 \%)$ each.

Table 2 showed levels of anxiety at pretest in the treatment group: 10 (50\%) severe anxiety, 8 (40\%) moderate anxiety, and 2 (10\%) mild anxiety. Furthermore, at the time of post-test results were obtained results 11 (55\%) experienced mild anxiety, 5 (25\%) moderate anxiety, 2 (10\%) severe anxiety, and $2(10 \%)$ not anxious. In the control group at the time of pre-test in the control group, 12 (60\%) had moderate anxiety, 4 (20\%) mild anxiety, and 4 (20\%) severe anxiety. Furthermore, at the time of post-test results were obtained results 13 (65\%) experienced moderate anxiety, 5 (25\%) mild anxiety, 2 (10\%) severe anxiety.

Table 3 showed results from the Mann Whitney test showed anxiety before intervention in the treatment group, and the control group obtained a p-value $=0.053$, meaning no difference $(p>0.05)$. While the level of anxiety after the intervention of the treatment group and the control group obtained a value of $\mathrm{p}$-value $=0.023$, which means there is a difference $(\mathrm{p}<0.05)$. The results of the Wilcoxon Signed Ranks test in the treatment group obtained a value of $p$ value $=0.000$, meaning there is a difference in 
anxiety values before and after. While in the control group obtained a value $\mathrm{p}$-value = 0.083 means there is no difference in anxiety values before and after in the control group.
The difference rate criteria in the Wilcoxon test $\mathrm{p}<0.05$, so it can be concluded that storytelling modified finger puppet use decreased anxiety in hospitalized children.

Table 1

Distribution of frequency of characteristics of children based on gender, and age in Srikandi Room Jombang Hospital in 2021

\begin{tabular}{|c|c|c|c|c|c|c|c|}
\hline \multirow{2}{*}{\multicolumn{2}{|c|}{ Characteristic }} & \multicolumn{2}{|c|}{$\begin{array}{c}\text { Treatment } \\
(n=20)\end{array}$} & \multicolumn{2}{|c|}{$\begin{array}{c}\text { Control } \\
(n=20)\end{array}$} & \multicolumn{2}{|c|}{$\begin{array}{c}\text { Total } \\
(\mathrm{N}=40)\end{array}$} \\
\hline & & $\mathbf{n}$ & $\%$ & $\mathbf{n}$ & $\%$ & $\mathbf{n}$ & $\%$ \\
\hline \multirow[t]{2}{*}{ Gender } & Male & 11 & 55.0 & 10 & 50.0 & 21 & 52.5 \\
\hline & Female & 9 & 45.0 & 10 & 50.0 & 19 & 47.5 \\
\hline \multirow{3}{*}{$\begin{array}{l}\text { Age } \\
\text { (years) }\end{array}$} & 4 & 8 & 40.0 & 6 & 30.0 & 14 & 35.0 \\
\hline & 5 & 8 & 40.0 & 8 & 40.0 & 16 & 40.0 \\
\hline & 6 & 4 & 20.0 & 6 & 30.0 & 10 & 25.0 \\
\hline
\end{tabular}

Table 2

Distribution of anxiety values in children before and after intervention in Srikandi Room Jombang Hospital in 2021

\begin{tabular}{llcccccccc}
\hline \multirow{3}{*}{ Variable } & \multicolumn{4}{c}{ Pre-Test } & \multicolumn{4}{c}{ Post-Test } \\
\cline { 3 - 10 } & \multirow{2}{*}{ Criteria } & \multicolumn{2}{c}{ Treatment } & \multicolumn{2}{c}{ Control } & Treatment & Control \\
\cline { 2 - 9 } Anxiety & No Anxiety & 0 & 0 & $\mathbf{n}$ & $\mathbf{0}$ & $\mathbf{n}$ & $\mathbf{\%}$ & $\mathbf{n}$ & $\mathbf{\%}$ \\
& Mild & 2 & 10 & 4 & 20 & 11 & 55 & 5 & 25 \\
& Moderate & 8 & 40 & 12 & 60 & 5 & 25 & 13 & 65 \\
& Severe & 10 & 50 & 4 & 20 & 2 & 10 & 2 & 10 \\
& Panic & 0 & 0 & 0 & 0 & 0 & 0 & 0 & 0 \\
\hline & Total & $\mathbf{2 0}$ & $\mathbf{1 0 0}$ & $\mathbf{2 0}$ & $\mathbf{1 0 0}$ & $\mathbf{2 0}$ & $\mathbf{1 0 0}$ & $\mathbf{2 0}$ & $\mathbf{1 0 0}$ \\
\hline
\end{tabular}

Table 3

Results of Mann Whitney and Wilcoxon Signed Ranks Test in children before and after intervention in Srikandi Room Jombang Hospital in 2021

\begin{tabular}{llccccc}
\hline \multirow{2}{*}{ Variable } & & \multicolumn{2}{c}{ Treatment } & \multicolumn{2}{c}{ Control } & Mann \\
\cline { 2 - 6 } & & Mean & SD & Mean & SD & Whitney \\
\hline \multirow{2}{*}{ Anxiety } & Pre-test & 3.40 & 0.681 & 3.00 & 0.649 & $\mathrm{p}=0.053$ \\
& Post-test & 2.35 & 0.813 & 2.85 & 0.587 & $\mathrm{p}=0.023$ \\
\hline Wilcoxon & & \multicolumn{2}{c}{$\mathrm{p}=0.000$} & $\mathrm{p}=0.083$ & \\
\hline
\end{tabular}




\section{DISCUSSION}

Anxiety is the assessment of emotion and a response to something dangerous, closely related to a state of helplessness and sureness [7]. Anxiety levels in pre-schoolers with hospitalization were measured using FAS (Faces Anxiety Scale) on average, experiencing moderate anxiety (50\%) and severe anxiety (30\%). This fact was found in other research [12] that 70\%, 20\%, and 5\% of preschool-age children experience moderatesevere and mild anxiety at the time of hospitalization. One factor that influences anxiety reactions is the child's developmental age [13]. Anxiety coping strategies have not fully evolved in children in preschool-age. Furthermore, they have been unable to acclimate to the hospital setting.

Many new experiences for children necessitate adaptation, such as meeting strangers, living and sleeping in a new location, and there is no freedom to play. Children of preschool age who are exposed to this find it difficult to communicate their concerns to their families, resulting in a high level of anxiety [14]. Various anxious reactions are shown by children during hospitalization, including regressive behavior, aggression, lack of cooperation, protest behavior, and difficulty to cooperate in carrying out treatment procedures [4]. Another impact of anxiety in children has a significant influence on the function of life if not fingered early, namely will be comorbid with other mental disorders and developmental disorders in children [5].

There needs to be immediate intervention in overcoming anxiety in children. Otherwise, it will cause fear and apathy, so that the child refuses to perform treatment procedures, treatments to extend the hospitalization period. All this will worsen the child's health condition and cause severity [12].

Play is a fun activity for children, overcoming various kinds of unpleasant feelings in child. By playing, children can feel happy and satisfied [7]. In-play therapy activities researchers also involve the role of parents because the involvement of parents in play therapy, in addition to improving social skills and abilities, can also provide positive emotional support and the child's ability to care for others.

The results of research that has been done showed that the modified storytelling of the use of finger puppets decreased anxiety in children who were hospitalized with a value of $\mathrm{p}=0.000$. Storytelling can provide $\mathrm{a}$ pleasant effect for children, so the brain will stimulate endorphins that can inhibit anxious stimulus sent to the BISA brain's [15]. Research conducted [3] also showed a significant influence of storytelling in play therapy in lowering anxiety levels in preschool children with hospitalization. Another study conducted [16] showed lower anxiety levels in preschool-age children hospitalized after getting storytelling therapy.

Researchers performed a storytelling modification strategy by using a finger puppet effectively to reduce anxiety. The results showed the effectiveness of finger puppet games against decreased fear in children before surgery, during, and postoperative [17]. Other studies have shown finger puppets may lower anxiety in children with leukemia 
in hospitals [18]. Finger puppets also showed significant differences in reducing anxiety in children with thalassemia [19]. During the implementation of the study, there were several stages carried out by researchers, including the introduction stage, researchers involving parents and companion nurses in a special playroom, the initial phase of implementation, namely children were assessed the level of anxiety using the FAS scale before the intervention. The stage of implementation of children shared storybooks about animals accompanied by their parents, researchers, and nurses while reading stories using finger puppets to demonstrate the activities of the animals being told. This storytelling activity lasted for 10 minutes and was carried out one time. Then the evaluation stage was carried out 30 minutes after the intervention, and the children assessed anxiety levels again to evaluate the results.

Play therapy activities with storytelling given to preschool-age children help open the mind and distract children from stressing conditions into not scary situations. In addition, it can also train children's creativity in their development, such as intellectual ability, sensitivity, the subtlety of mind, emotions, art, fantasizing, and imagination of children. It develops the power of the left brain and the right brain so that storytelling therapy can effectively reduce anxiety in children due to hospitalization [20]. Furthermore, researchers can further examine more deeply the effectiveness of parental involvement in storytelling play therapy.

\section{CONCLUSION}

Storytelling strategies using finger puppets can decrease anxiety levels in preschool-age children who are hospitalized. Storytelling activities can distract children, turn stress conditions into pleasant circumstances, thus stimulating endorphins in suppressing anxiety in the brain. This pleasant condition will make the child cooperate in the treatment process while in the hospital. In addition, other benefits obtained from this activity is that it can improve children's intellectual abilities, ability to socialize, sensitivity/concern for others, thus developing the ability of the right brain and left brain. It is also necessary for the parents or families' involvement in providing emotional support to children so that the results are more effective.

Storytelling play therapy activities using finger puppets can be applied to reduce anxiety in children during hospitalization, and better parents and families are involved. It is expected that in the future, it can be used as an alternative method to reduce anxiety.

\section{ACKNOWLEDGMENTS}

The authors sincerely acknowledge the contributions of KEMENRISTEKDIKTI, LLDIKTI VII, STIKes Bahrul Ulum Jombang, General Hospital Jombang, Other contributors including all facilitators and research assistants are also appreciated and acknowledged. 


\section{REFERENCES}

[1] Kementerian Kesehatan Republik Indonesia, "Buku Kesehatan Ibu dan Anak," Jakarta, 2015.

[2] M. Idris and M. Reza, "Efektifitas Terapi Bermain (Mewarnai) Terhadap Penurunan Kecemasan Akibat Hospitalisasi Pada Anak Usia Prasekolah (3-6 Tahun) Di Ruang Melati RSUD Kota Bekasi," J. AFIAT “Kesehatan Jiwa," vol. 4, no. 2, pp. 583-592, 2018.

[3] M. Yati, S. Wahyuni, and I. Islaeli, "The Effect of Storytelling in a Play Therapy on Anxiety Level in Pre-School Children During Hospitalization in the General Hospital of Buton," Public Heal. Indones., vol. 3, no. 3, pp. 96-101, 2017, doi: 10.36685/phi.v3i3.134.

[4] S. Pourteimour and S. Kazemi, "The effectiveness of the robotic game kit on anxiety among hospitalized preschool children: A non-randomized controlled trial," Nurs. Pract. Today, vol. 8, no. 4, pp. 273-283, 2021, doi: 10.18502/NPT.V8I4.6703.

[5] W. O. Nursanaa and I. N. C. Ady, "Play Therapy for Children with Anxiety Disorders," in 5th ASEAN Conference on Psychology, Counselling, and Humanities (АCPCH 2019), 2020, vol. 395, no. Acpch 2019, pp. 81-86, doi: 10.2991/assehr.k.200120.018.

[6] I. N. Nur Oktavia Hidayati, Ajeng Andini Sutisnu, "Efektivitas Terapi Bermain Terhadap Tingkat Kecemasan Anak Yang Menjalani Hospitalisasi," J. Keperawatan BSI, vol. 9, no. 1, pp. 61-67, 2021.

[7] H. Saputro and I. Fazrin, Anak Sakit Wajib
Bermain di Rumah Sakit: Penerapan Terapi Bermain Anak Sakit; Proses, Manfaat dan Pelaksanaannya. Ponorogo: Forum Ilmiah Kesehatan (FORIKES), 2017.

[8] W. H. C. Li, J. O. K. Chung, K. Y. Ho, and B. M. C. Kwok, "Play interventions to reduce anxiety and negative emotions in hospitalized children," BMC Pediatr., vol. 16, no. 1, pp. 1-9, 2016, doi: 10.1186/s12887-016-0570-5.

[9] Z. Sekhavatpour, N. Khanjani, T. Reyhani, S. Ghaffari, and M. Dastoorpoor, "The effect of storytelling on anxiety and behavioral disorders in children undergoing surgery: a randomized controlled trial," Pediatr. Heal. Med. Ther., vol. 10, pp. 61-68, 2019, doi: 10.2147/phmt.s201653.

[10] Jumasing and S. Patima, "Terapi dongeng si kancil terhadap penurunan kecemasan anak hospitalisasi di rsud haji makassar," Alauddin Sci. J. Nurs., vol. 1, no. 2, pp.6672, 2021.

[11] D. Apriany, S. N. Aban, and I. Bola, "Pengaruh Bermain Mewarnai Lukisan Pasir terhadap Tingkat Kecemasan Anak Usia Prasekolah yang Menggalami Hospitalisasi di Ruang C6 RSUD Cibabat Cimahi," J. Kesehat. Kartika, vol. 15, no. 3, pp. 28-39, 2020.

[12] S. R. Dalei, G. R. Nayak, and R. Pradhan, "Effect of art therapy and play therapy on anxiety among hospitalized preschool children," J. Biomed. Sci., vol. 7, no. 2, pp. 71-76, 2020, doi: 10.3126/jbs.v7i2.34006.

[13] D. L. Wong, Pedoman Klinis Perawatan Pediatrik Edisi Buku Kedokteran. Jakarta: 
EGC, 2009.

[14] N. L. Wati, N. M. N. Sukmayanti, and R. Kartikasari, "The Relationship Between Therapeutic Communication and Level of Anxiety Among Hospitalized Preschool Children," KnE Life Sci., vol. 2019, pp. 870-879, 2019, doi: 10.18502/kls.v4i13.5346.

[15] J. R. Legi, S. Sulaiman, and N. H. Purwanti, "Pengaruh storytelling dan guidedimagery terhadap tingkat perubahan kecemasan anak usia prasekolah yang dilakukan tindakan invasif," $J$. Telenursing, vol. 1 , no. 1 , pp. 145-156, 2019, doi: https://doi.org/10.31539/joting.v1i1.4 96.

[16] P. Pawiliyah and L. Marlenis, "Pengaruh Terapi Bermain Mendongeng dengan Penurunan Tingkat Kecemasan pada Anak Usia Pra Sekolah Akibat Hospitalisasi," J. Keperawatan Silampari, vol. 3, no. 1, pp. 271-280, 2019, doi: https://doi.org/10.31539/jks.v3i1.788.

[17] M. A. Kostak, G. Kutman, and R. Semerci, "The effectiveness of finger puppet play in reducing fear of surgery in children undergoing elective surgery: A randomised controlled trial," Elsevair, vol. 28, no. 4, pp. 415-421, 2021, doi: https://doi.org/10.1016/j.colegn.2020. 10.003.

[18] K. Behera, A. Tripathi, A. Basu, and P. R. Sethy, "Effect of Puppet Therapy On Reduction Of Anxiety Among Childrens (6-12 Years) Suffering From Leukemia In Selected Hospitals," Eur. J. Mol. Clin. Med., vol. 07, no. 10, pp. 3849-3859, 2020.

[19] L. O. Manalu, B. Rustandi, and B. Somantri, "Effect of Puppet Play Therapy on Anxiety in Preschoolers with Thalassemia at the Thalassemia Polyclinic at Al-Ihsan Baleendah Hospital, Bandung Regency," in The 4th International Virtual Conference on Nursing, 2021, vol. 2021, pp. 758-769, doi: 10.18502/kls.v6i1.8752.

[20] W. T. Astuti and N. Faiqoh, "Literature Review : Penerapan Terapi Story Telling Terhadap Kecemasan Anak Prasekolah Akibat Hospitalisasi," J. Keperawatan Karya Bhakti, vol. 7, no. 1, pp. 11-24, 2021. 